\title{
Molecular characterization of Trichomonas gallinae isolates recovered from the Canadian Maritime provinces' wild avifauna reveals the presence of the genotype responsible for the European finch trichomonosis epidemic and additional strains.
}

\begin{tabular}{|r|l|}
\hline Journal: & Parasitology \\
\hline Manuscript ID: & PAR-2014-0382.R2 \\
\hline Manuscript Type: & Research Article - Standard \\
\hline Date Submitted by the Author: & n/a \\
\hline Complete List of Authors: & $\begin{array}{l}\text { McBurney, Scott; University of Prince Edward Island,, Department of } \\
\text { Pathology \& Microbiology; Canadian Wildlife Health Cooperative, Atlantic } \\
\text { Region } \\
\text { Kelly-Clark, Whitney; University of Prince Edward Island,, Department of } \\
\text { Pathology \& Microbiology } \\
\text { Forzán, María; University of Prince Edward Island,, Department of } \\
\text { Pathology \& Microbiology } \\
\text { Lawson, Becki; Zoological Society of London, Institute of Zoology } \\
\text { Tyler, Kevin; UEA, School of Medicine } \\
\text { Greenwood, Spencer; University of Prince Edward Island, Biomedical } \\
\text { Sciences }\end{array}$ \\
\hline Key Words: & $\begin{array}{l}\text { Trichomonas gallinae, trichomonosis, genotype, ITS, Fe-hydrogenase, } \\
\text { subtype, finch, pigeon }\end{array}$ \\
\hline
\end{tabular}

\section{SCHOLARONE}

Manuscripts 
1 Molecular characterization of Trichomonas gallinae isolates recovered from the

2 Canadian Maritime provinces' wild avifauna reveals the presence of the genotype responsible for the European finch trichomonosis epidemic and additional

4 strains.

5 Scott McBurney ${ }^{1,2}$, Whitney K. Kelly-Clark ${ }^{1,2}$, María J. Forzán ${ }^{1,2}$, Becki Lawson ${ }^{3}$, Kevin

$6 \quad$ M. Tyler ${ }^{4}$ and Spencer J. Greenwood ${ }^{5}$

7

8 1- Department of Pathology \& Microbiology, Atlantic Veterinary College, University of

9 Prince Edward Island, 550 University Avenue, Charlottetown, PE, C1A 4P3, Canada

10 Prince Edward Island, Canada

11 2- Canadian Wildlife Health Cooperative, Atlantic Region, Atlantic Veterinary College,

12 University of Prince Edward Island, 550 University Avenue, Charlottetown, PE, C1A

13 4P3, Canada Prince Edward Island, Canada

14 3- Institute of Zoology, Zoological Society of London, Regents Park, London, NW1 4RY, 15 UK

16 4- Norwich Medical School, University of East Anglia, Norwich, NR4 7TJ, UK

17 5- Department of Biomedical Sciences, Atlantic Veterinary College, University of Prince

18 Edward Island, 550 University Avenue, Charlottetown, PE, C1A 4P3, Canada Prince

19 Edward Island, Canada

21 Running title: Molecular characterization of T. gallinae in Canadian wild avifauna

22 Corresponding author: Spencer J. Greenwood, Tel: 902-566-6002, Fax: 902-566-

23 0832, e-mail: sgreenwood@upei.ca 


\section{Summary (150-200 words)}

Finch trichomonosis, caused by Trichomonas gallinae, emerged in the Canadian Maritime provinces in 2007 and has since caused ongoing mortality in regional purple finch (Carpodacus purpureus) and American goldfinch (Carduelis tristis) populations. Trichomonas gallinae was isolated from (1) finches and rock pigeons (Columbia livia) submitted for post mortem or live-captured at bird feeding sites experiencing trichomonosis mortality; (2) bird seed at these same sites; and (3) rock pigeons livecaptured at known roosts or humanely killed. Isolates were characterized using internal transcribed spacer (ITS) region and iron hydrogenase (Fe-hyd) gene sequences. Two distinct ITS types were found. Type A was identical to the UK finch epidemic strain and was isolated from finches and a rock pigeon with trichomonosis; apparently healthy rock pigeons and finches; and bird seed at an outbreak site. Type B was obtained from apparently healthy rock pigeons. Fe-hyd sequencing revealed six distinct subtypes. The predominant subtype in both finches and the rock pigeon with trichomonosis was identical to the UK finch epidemic strain A1. Single nucleotide polymorphisms in Fe-hyd sequences suggest there is fine-scale variation amongst isolates and that finch trichomonosis emergence in this region may not have been caused by a single spillover event.

Keywords: Trichomonas gallinae, trichomonosis, genotype, ITS, Fe-hydrogenase, subtype, finch, pigeon 
45 Key Findings ( $3-5$ bullets of $<90$ characters each, including spaces)

46

47

48

49

50

51

52

53

54

55

56

57

58

59

60

61

62

5

- Two T. gallinae ITS sequence types found in the Canadian Maritime provinces' avifauna

- T. gallinae ITS sequence type in Canadian finches identical to UK finch epidemic strain

- Bird seed from an outbreak yielded T. gallinae with the UK finch epidemic strain ITS sequence

- Fe-hyd gene sequencing revealed fine-scale variation with six T. gallinae subtypes

- Fe-hyd subtype of the UK finch epidemic strain was predominant in Canadian finches

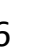

7

9

1

2




\section{Introduction}

Trichomonas gallinae is a protozoan parasite which commonly infects the upper digestive tract of columbids (i.e., pigeons and doves) and birds of prey (i.e., eagles, hawks and owls) and less frequently can also infect a variety of other avian taxa including passerines (such as finches and sparrows) (Forrester and Foster; 2009; Amin et al. 2014). In 2005, trichomonosis was first recognized as an emerging infectious disease of wild finches in Great Britain (GB) (Pennycott et al. 2005; Lawson et al. 2006).

The species affected in the summer/autumn seasonal epidemic were primarily greenfinch (Chloris [Carduelis] chloris) and chaffinch (Fringilla coelebs). Although preexisting sporadic reports of disease in free-ranging finches do exist, the 2005-2006 (and on-going) outbreak is the first reported instance of large-scale epidemic mortality due to trichomonosis in any passerine species (Lawson et al. 2012). In the years following the initial outbreak in the western and central counties of England and Wales, finch trichomonosis spread to eastern England (2007) and then to southern Fennoscandia (2008) and Germany (2009); epidemiological and historical banding return data supported chaffinch migration as the most likely mechanism of the observed pattern of disease spread (Neimanis et al. 2010; Robinson et al. 2010; Lawson et al. 2011a, Peters et al. 2009). The disease range of finch trichomonosis has continued to extend further eastward within continental Europe and had reached Austria and Slovenia by 2012 (Ganas et al. 2014). Concurrently, finch trichomonosis spread westward from Britain with finch mortality incidents reported in Northern Ireland from 2006 and in the Republic of Ireland from 2007 (Lawson et al. 2012). 
In the late summer/early autumn of 2007 , trichomonosis was first recognized in

86

87 the purple finch (Carpodacus purpureus) populations of Nova Scotia, Canada (Forzán et al. 2010). In the following summer and autumn, the Canadian Wildlife Health Cooperative (CWHC), Atlantic region, confirmed additional Canadian mortalities from trichomonosis in the purple finch populations of Nova Scotia and Prince Edward Island (PEI) and in American goldfinch (Carduelis tristis) populations of New Brunswick (Forzán et al. 2010). In 2009, the CWHC confirmed finch trichomonosis incidents in all three Canadian Maritime provinces during the same seasons, and diagnosed the disease in a new species, the pine siskin (Carduelis pinus) (CWHC unpublished data). The diagnosis of trichomonosis in the Canadian Maritime provinces in the summer and autumn of three consecutive years and the infection of multiple finch species not known to be previously affected by the disease, suggests that finch trichomonosis is an emerging disease in this region. Prior to the emergence of trichomonosis in the passerine bird populations of the Canadian Maritime provinces, this disease was not diagnosed in any of the region's wild avian species since the CWHC, Atlantic Region, began collecting diagnostic wildlife health data in 1992. While it is assumed that $T$. gallinae is present in the columbid populations of the Canadian Maritime provinces due to the parasite's ubiquitous distribution in wild pigeon and dove populations worldwide (Amin et al. 2014), to our knowledge reports of $T$. gallinae in the region's columbid populations have not been documented. Lastly, it is noteworthy that the Canadian Maritime provinces represent the eastern limit of North America with closest geographical proximity to the UK and that finch trichomonosis emerged in the years immediately subsequent to the onset of epidemic mortality in British finches. 
The aims of the present study were to firstly investigate the sequence diversity of

109

110

111

112

113

114

115

116

117

T. gallinae recovered from finches and columbids from the Canadian Maritime provinces. Secondly, to compare the Canadian T. gallinae sequences with those published from other countries, including isolates from GB. Finally, to provide a description of the temporal, geographical and species-specific variation amongst the isolates examined from the Canadian Maritime provinces. Genotyping of isolates was determined by polymerase chain reaction (PCR) and sequencing of the ITS region (5.8S rDNA and flanking internal transcribed spacer regions, ITS1 and ITS2) and the hydrogenosomal Fe-hydrogenase (Fe-hyd) gene to evaluate finer scale evolutionary relationships amongst these organisms (Lawson et al. 2011b; Chi et al. 2013).

\section{Materials and Methods}

Columbid and passerine capture methods

When suspected finch trichomonosis incidents in the Canadian Maritime provinces were reported by members of the public, the CWHC, Atlantic region, facilitated the immediate submission of recently dead passerines by encouraging property owners to submit specimens for a detailed post-mortem examination (PME). When PME confirmed trichomonosis (on the basis of gross and microscopic lesions or microscopic lesions alone consistent with trichomonosis with or without a positive culture of Trichomonas sp. from upper alimentary tract lesions), the site was visited to live-capture all species of birds present and sample them for Trichomonas sp. by culture (see culture technique below). In addition, food and water sources provided at these 
129 sites were individually sampled for Trichomonas $\mathrm{sp}$. by culture (see culture technique 130 below).

To investigate the heterogeneity of $T$. gallinae in sympatric columbid populations

132 in PEI, known locations of high columbid population densities were selected for

133 extensive trapping, without pre-existing knowledge of the presence of $T$. gallinae or 134 trichomonosis within these populations.

All birds were captured under a Canadian Wildlife Federation license (permit \#SC2707) and Canadian Council on Animal Care guidelines (UPEI protocol \#10-020, 6003687) by standard methods including mist net, whoosh net, and walk-in box trap. Passerines were captured for this study by using a mist net (Bleitz Wildlife Foundation 139 California, 50D-2 ply mesh, 11/2" mesh, 7’ X 42', Stock \# 26N-50/2) for two days per location in May-September of 2009 and 2011. Columbid species required extensive

141 time for acclimatization to the box trap, and as a result, columbids were ground trapped 142 at each site on multiple days sometimes occurring over a period of several weeks in 143 May-December of 2009 and 2010. A ground box trap (Safeguard single compartment 144 pigeon trap, 28"L $\times 24 " \mathrm{~W} \times 8$ "H, with eight entry doors, and a capacity to hold up to 30

145 birds) was baited with bird seed for a minimum of 12 days prior to commencing 146 trapping. It is important to note that during the allotted baiting period, all regular 147 supplementary feed sources were removed from the property to ensure the birds fed in 148 the baited area. Mourning dove, another target species, were difficult to capture with the 149 ground box trap so their capture was also facilitated by use of a whoosh-net (Hawkseye 150 Nets Virginia Beach, VA, USA - 2 1/8" mesh, 23' whoosh net). Similar to the box-trap 
151 protocol, the area over which the whoosh-net was fired was baited with bird seed for a 152 minimum of 5 days prior to attempted capture.

Birds captured by all methods were sexed and aged by plumage (hatch year or

154 adult) when possible, weighed, banded and examined for clinical signs consistent with 155 trichomonosis such as the typical oropharyngeal lesions, fluffed up feathers, saliva on 156 the face, food at the commissures of the beak or matted in the feathers of the head or 157 chest and/or reluctance or inability to fly. If $T$. gallinae was isolated from a bird with no 158 clinical evidence of trichomonosis it was designated as "apparently healthy". If $T$. 159 gallinae was isolated from a bird with clinical signs consistent with trichomonosis, the 160 infection was defined as a clinical case of trichomonosis. Opportunistic sampling was 161 also undertaken for Trichomonas sp. by culture of wild passerines and columbids 162 admitted to the Atlantic Veterinary College Teaching Hospital and of rock pigeons that 163 were humanely killed during removal from cattle barns in the winter months on PEI.

Trichomonad culture

Prior to swabbing live birds, the end of a sterile calcium-alginate cotton-tipped swab with an aluminum shaft (Puritan ${ }^{\mathrm{TM}}$ Medical, Fisher Scientific, Canada, catalogue

167 number 22-029-501) was bent into a gentle curve representing $\sim 120^{\circ}$ angle to match 168 the natural anatomical curvature of the oral cavity as it opens into the esophagus. The 169 distance between the start of the curve and cotton tip was equivalent to the distance 170 between the oral cavity and crop, and the positioning of this curve depended on the 171 species of bird. Anatomically, bending the swab at the $120^{\circ}$ angle facilitated the 172 movement of the swab from the oral cavity to the crop. After bending, the swab was 
173 moistened with sterile saline and gently inserted into the oral cavity of the bird by

174 pushing the tip against a commissure of the beak. The swab was slowly and gently

175 advanced into the esophagus to the level of the crop while allowing the bird to swallow.

176 Due to the thinness of the esophageal and ingluvial walls in passerine birds this

177 procedure was done with extreme caution and only by experienced individuals to avoid

178 iatrogenic damage. Once in the crop, the swab was gently rotated, moved up and down

179 and removed. Care was taken to swab any visible oropharyngeal trichomonosis lesions.

180 The crop and lesions of dead birds were swabbed once the upper digestive tract was

181 opened for PME. After collection, all swabs were used to immediately inoculate an

182 InPouch TF ${ }^{\mathrm{TM}}$ test medium kit (BioMed Diagnostics, White City, OR, USA) on-site prior

183 to transport back to the laboratory for incubation at $37^{\circ} \mathrm{C}$ and daily monitoring for 10

184 days. If the site was not in the province of PEI, the samples were placed in a Hova-

185 Bator egg incubator (circulated air model no. 2362N, 20.3 watt, 115 volt AC,

186 G.Q.F.MFG. Co. Inc. Savannah, GA) set at $37^{\circ} \mathrm{C}$ for transport to the laboratory at the

187 University of Prince Edward Island.

Bird seed and water sources at sites experiencing trichomonosis mortality were

189 independently swabbed. The swabs were used to immediately inoculate an InPouch

$190 \mathrm{TF}^{\mathrm{TM}}$ test medium kit on-site prior to transport back to the laboratory for incubation at

$19137^{\circ} \mathrm{C}$ and daily monitoring for 10 days. If the site was not in the province of PEI, the

192 samples were placed in a Hova-Bator egg incubator for transport to the laboratory at the

193 University of Prince Edward Island as described above.

194 Parasite culture and cryopreservation 
Parasite cultures were monitored daily using a double chamber hemacytometer, counts of motile trichomonads were performed on both grids and if results did not correlate within $10 \%$, the process was repeated and the average of the four counts was taken instead of the two. Once parasites reached mid-log phase, they were cryopreserved by adding $100 \mu \mathrm{l}$ of $100 \%$ glycerol to $1 \mathrm{ml}$ of the parasite culture. This total volume was subdivided into four separate $500 \mu \mathrm{l}$ aliquots and stored in liquid nitrogen. An additional $1 \mathrm{ml}$ aliquot of the original parasite culture was collected to be used for

202 DNA extraction.

PCR for ITS region and Fe-hyd gene regions

Trichomonas sp. DNA was obtained from culture isolates using a QIAamp DNA Mini Kit (QIAGEN, Toronto, ON, Canada) as per the manufacturer's instructions for cell cultures. DNA extracts of 42 isolates (Table 1) were examined using PCR protocols specific for the ITS1/5.8S rRNA/ITS2 region (subsequently referred to as the ITS region) and Fe-hyd gene. DNA amplification of the ITS region ( $300 \mathrm{bp})$ was performed using trichomonad-specific primers TFR1 (5'-TGCTTCAGTTCAGCGGGTCTTCC-3') and TFR2 (5'-CGGTAGGTGAACCTGCCGTTGG-3') (Felleisen 1997) while amplification of

211 the Fe-hyd gene ( $900 \mathrm{bp})$ used the primers TrichhydFOR (5'-

212 GTTTGgGATGgCCTCAGAAT-3') and TrichhydREV (5'-

213 AGCCGAAGATGTTGTCGAAT-3') (Lawson et al. 2011b; Chi et al. 2013). Each PCR 214 reaction mixture contained 12.5 $\mu$ I Amplitaq Gold Master Mix (Applied Biosystems, Life

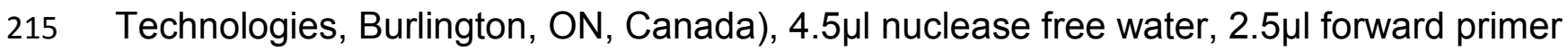
$216(10 \mu \mathrm{M}), 2.5 \mu \mathrm{l}$ reverse primer $(10 \mu \mathrm{M})$ and $3 \mu \mathrm{l}$ of undiluted target DNA and was 
217 performed in duplicate. For each reaction, negative controls substituted target DNA with

$2183 \mu \mathrm{l}$ of nuclease-free water and positive controls used $3 \mu \mathrm{l}$ of T. gallinae DNA (purple

219 finch isolate from Forzán et al. 2010; parasite species confirmed by sequencing the ITS

220 region) and $T$. gallinae DNA from a British greenfinch (species confirmed by sequencing

221 the Fe-hyd gene) respectively. PCR parameters for the ITS region amplification were

$22294^{\circ} \mathrm{C}$ for 2 minutes, followed by 40 cycles of $94^{\circ} \mathrm{C}$ for 30 seconds, $67^{\circ} \mathrm{C}$ for 30 seconds,

$22372^{\circ} \mathrm{C}$ for 2 minutes and a final extension at $72^{\circ} \mathrm{C}$ for 15 minutes. PCR parameters for

224 Fe-hyd gene amplification were $94^{\circ} \mathrm{C}$ for 15 minutes, followed by 35 cycles of $94^{\circ} \mathrm{C}$ for 1

225 minute, $66^{\circ} \mathrm{C}$ for 30 seconds, $72^{\circ} \mathrm{C}$ for 1 minutes and a final extension at $72^{\circ} \mathrm{C}$ for 5

226 minutes. PCR amplicons were then examined via $1 \%$ agarose gel electrophoresis with

227 ethidium bromide.

DNA sequencing and phylogeny reconstruction

PCR products were sequenced in both directions at the McGill University and

Genome Québec Innovation Centre, Montréal, Québec, Canada. Sequences were

231

aligned with published trichomonad sequences from GenBank using BioEdit (Hall 1999). Phylogenies were constructed separately for the ITS region and Fe-hyd gene by neighbour-joining (NJ), maximum parsimony (MP) and maximum likelihood (ML) methods using MEGA version 6.0 (Tamura et al. 2013). Statistical support for NJ, ML, 235 and MP tree topologies were bootstrap-sampled 1,000 times and support values (\%) of $\mathrm{NJ}, \mathrm{MP}$ and $\mathrm{ML}$ analysis were superimposed on the $\mathrm{NJ}$ consensus trees. 
239 were reported in the units of the number of base substitutions per site. The MP tree was

240 obtained using the Subtree-Pruning-Regrafting algorithm (Nei and Kumar 2000) with

241 search level 1 in which the initial trees were obtained with the random addition of

242 sequences (10 replicates). The ML tree was constructed using Jukes-Cantor

243 substitution model (Jukes and Cantor 1969) as determined by the lowest Bayesian

244 Information Criterion (BIC) score and highest Akaike Information Criterion, corrected

245 (AICc) value (Tamura et al. 2013). Initial tree(s) for the heuristic search were obtained

246 by applying the $\mathrm{NJ}$ method to a pairwise distance matrix estimated using Maximum

247 Composite Likelihood (MCL). For ITS region trees, there were a total of 37 nucleotide

248 sequences using 209 positions in the final dataset. All positions containing gaps and

249 missing data were eliminated. Bootstrap values (1000 replicates) for each NJ, MP and

$250 \mathrm{ML}$ trees were computed following Felsenstein (1985).

For phylogeny reconstruction based on the Fe-hyd gene, the NJ, MP and ML

252 used the same parameters as for the ITS region sequences including bootstrap

253 replicates (1000). For Fe-hyd trees, there were 15 nucleotide sequences with a total of

254803 positions in the final dataset. All positions containing gaps and missing data were 255 eliminated.

256 Results

257 Parasite recovery from columbids, finches and environmental samples

258 Forty-two trichomonad isolates were collected between 2009 and 2011 from rock

259 pigeons $(n=12)$, finch species $(n=29)$ and bird seed $(n=1)$ from the Canadian

260 Maritime provinces (Table 1 and Figure 1). Thirty-seven live mourning doves were 
261 captured, swabbed and cultured for this study, and none of these individuals were

262 positive for T. gallinae. Additionally, no water samples were positive for T. gallinae. In

263 the individuals that died of trichomonosis, no gross or microscopic lesions consistent

264 with another disease being the primary problem (e.g., avipoxvirus infection or

265 salmonellosis) were identified at post mortem or with histopathology.

266 ITS region sequence and phylogeny

ITS region sequences of 300 nucleotides were derived for the 42

268 trichomonad isolates recovered from finches, rock pigeons and from a bird seed sample

269 in the Canadian Maritime provinces. Two distinct ITS region types were recognized that

270 share 98.5\% similarity, (1) Sequence Type A (GenBank: KF214772) was identified in 39

271 T. gallinae isolates collected from American goldfinches ( $n=7 ; 5$ apparently healthy

272 individuals and 2 with trichomonosis), purple finches ( $n=22 ; 8$ apparently healthy

273 individuals and 14 with trichomonosis), rock pigeons ( $n=9 ; 8$ apparently healthy

274 individuals and 1 with trichomonosis ) and an aggregate of moist bird seed removed

275 from several birdfeeders and deposited in a compost bin at a site confirmed to be

276 experiencing finch trichomonosis $(n=1)$ and (2) Sequence Type B (GenBank:

277 KF214773) was identified in T. gallinae isolates from 3 apparently healthy rock pigeons

278 (Table 1).

The ITS region phylogeny confirms that the $T$. gallinae isolates formed a

280 monophyletic assemblage within the trichomonads with two well-supported groups,

281 Type A \& B (Figure 2). Type A contains 39 PEI isolates from finches and rock pigeons

282 as well as the bird seed sample (GenBank: KF214772) and also representative isolates 
283 including the UK finch epidemic strain (GenBank: GQ150752) and other isolates from 284 finches, columbids and raptors from Brazil, Europe, Mauritius, Australia and the USA 285 (Figure 2). Type B contains an additional three isolates derived from PEI rock pigeons 286 (GenBank: KF214773) with no evidence of trichomonosis, along with representative 287 isolates derived from columbids, raptors and a canary from diverse geographic regions 288 including the USA, Europe and Australia (Figure 2).

Fe-hyd gene sequence and phylogeny

The Fe-hyd nucleotide sequences (901 nucleotides) were obtained from all finch and rock pigeon isolates from the Canadian Maritime provinces $(n=41)$. Multiple

292 attempts to amplify the Fe-hyd gene from DNA extracted from the bird seed sample 293 (isolate 42) were unsuccessful. Six different Fe-hyd sequence subtypes were 294 discovered that share between $98.1-99.8 \%$ similarities. The six Fe-hyd subtypes 295 identified in the present study are indicated in Table 1. The first subtype (GenBank: 296 KJ184167) included American goldfinch isolates 1-6, purple finch isolates 8, 11-17 and 297 19-29 and rock pigeon isolates 32, 34-35 and 37-38 that were identical to the clonal UK 298 finch epidemic strain (GenBank: JF681136, Lawson et al. 2011b). The second subtype 299 (GenBank: KJ184168) included purple finch isolates 9 and 10, while the third subtype 300 (GenBank: KJ184169) included American goldfinch isolate 7 and purple finch isolate 18 301 respectively; each subtype differed by one unique single nucleotide polymorphism 302 (SNP) from the UK finch epidemic strain A1. Similarly, the fourth subtype (GenBank: $303 \mathrm{KJ} 184170)$ from rock pigeon isolate 39 was identical to an isolate from a Madagascar 304 turtle dove (Streptopelia picturata) from the Seychelles (GenBank: JF681141), while the 
305 fifth subtype (GenBank: KJ184171) from rock pigeon isolate 40 differed by one SNP. 306 The sixth subtype (GenBank: KJ184172) included rock pigeon isolates 33, 36 and 41 307 that were identical to an isolate from a wood pigeon (Columba palumbus) from the UK 308 (GenBank: KC529662). The Fe-hyd phylogeny shows two distinct clusters of sequences. Isolates 1-6, 8, 11-17, 19-32, 34-35 and 37-38 (GenBank: KJ184167), isolates 7 and 18 from American 311 goldfinch and purple finch (GenBank: KJ184169) and the isolate from purple finches 9 312 and 10 (GenBank: KJ184168) all grouped with the UK finch epidemic strain A1 313 (GenBank: JF681136). The second cluster contains the two PEI rock pigeons isolates 31439 and 40 (GenBank: KJ184170 and KJ184171 respectively) in a well-supported (98\% 315 by all three phylogeny methods) cluster with an isolate from a Madagascar turtle dove 316 from the Seychelles (A2) (Figure 3). 320 cohesive branching structure (Figure 3.).

\section{Discussion}

This study utilised ITS region and the Fe-hyd gene sequencing to investigate the

323 genetic diversity of $T$. gallinae in finch and columbid populations of the Canadian

324 Maritime provinces following the emergence of finch trichomonosis in this region. 
The ITS region analysis revealed that two $T$. gallinae sequence types are present

326

327

328

329 in the wild avifauna of the Canadian Maritime provinces. In phylogenies based on ITS region sequence data, $T$. gallinae splits into two very distinct groups as noted by previous authors (Gerhold et al. 2008; Sansano-Maestre et al. 2009; Grabensteiner et al. 2010, Lawson et al. 20011b).

All finch isolates in this study, whether they originated from apparently healthy birds or birds with trichomonosis, were identical to the $T$. gallinae Type A that has been previously identified in European finches and is widespread in North American columbids (Gerhold et al. 2008; Lawson et al. 2011b; Girard et al. 2014). Importantly, this same type was identified in nine rock pigeons (eight apparently healthy individuals and one with trichomonosis) (Table 1). Thus, the ITS region sequence typing alone cannot discriminate whether the origin of trichomonosis in finches in the Canadian Maritime provinces is a translocation of the European finch strain or is simply the result of contact with infected sympatric columbids. However, because both American goldfinch and purple finch populations in the Canadian Maritimes are considered local resident populations with limited distance North-South migrations (mainly associated with weather conditions and food availability) and rock pigeons are non-migratory yearround residents, a plausible scenario for transmission between these species at local bird feeding stations is reasonable without requiring movement of the disease from Europe to the Canadian Maritime provinces.

A common factor in the emergence of trichomonosis in finches in all geographical locations is that the mortality is identified where large numbers of birds congregate at private birdfeeding and watering stations (Forzán et al. 2010; Neimanis et al. 2010; 
348 Robinson et al. 2010). Therefore, it has been suggested that indirect transmission 349 associated with contaminated bird seed, water bowls, or bird baths plays a role in the 350 epidemiology of this disease (Boal et al. 1999; Neimanis et al. 2010; Robinson et al. 351 2010; Gerhold et al. 2013). In the present study, T. gallinae was not detected in water 352 collected from sites where trichomonosis mortalities were occurring. This was surprising 353 given that Bunbury et al. (2007) were successful in recovering T. gallinae from puddles 354 and Gerhold et al. (2013) found that T. gallinae was able to survive for up to 20 minutes 355 in both distilled and chlorinated water when organic matter (detritus, leaves and soil) 356 was present. One caveat to our water sampling success was that property owners 357 undergoing bird mortalities in their backyards became more diligent in cleaning feeders 358 and waterers. Thereby reducing the likelihood of recovering parasites from water 359 samples collected in our study. In support of this fact, the only successful isolation of $T$. gallinae from bird seed was from a composite sample disposed of in a compost bin at a property experiencing trichomonosis mortality. This isolation supports the experimental evidence that showed T. gallinae can survive in moist grain for 120 hours (Kocan 1969).

363 Furthermore, ITS typing confirmed that the bird seed isolate was Type A, identical to $T$. gallinae isolates recovered from sick birds on the same property. Interestingly, we also identified three rock pigeons infected with Type B $T$. 366 gallinae, a type that has been reported in columbids from the USA, eastern Spain and 367 Austria as well as in raptors from eastern Spain (Gerhold et al. 2008; Sansano-Maestre 368 et al. 2009). In a prevalence study of T. gallinae, Sansano-Maestre et al. (2009) examined pigeons and raptors with gross lesions consistent with trichomonosis and apparently healthy birds with no identifiable lesions and found that Type A $T$. gallinae 
371 were recovered more frequently from birds with gross lesions of trichomonosis, whereas

372 Type B T. gallinae were recovered from individuals with no lesions, suggesting a

373 relationship between Type A and increased virulence. Sansano-Maestre et al. (2009)

374 also speculated that Type B parasites may be adapted to pigeon hosts as this Type was

375 much more prevalent in pigeons than in raptors. Similar to Sansano-Maestre et al.

376 (2009) study, we found that all Type B isolates were recovered from apparently healthy

377 rock pigeons, and all finch species and rock pigeons with evidence of clinical

378 trichomonosis were infected with Type A. However, it is important to note that while all

379 isolates recovered from either finches or pigeons with clinical evidence of trichomonosis were Type A, Type A isolates were also recovered from apparently healthy birds. Also,

381 while rock pigeon isolates were not all Type B, all Type B isolates in our study were 382 recovered exclusively from rock pigeons, all of which were apparently healthy

383 individuals. Thus our results are consistent with the hypothesis put forward by Sansano-

384 Maestre et al. that there may be a relationship between Type A and increased virulence.

Through examination of multiple gene regions (ITS region, Fe-hyd gene and small sub-unit rDNA), as well as random amplified polymorphic DNA analyses, Lawson et al. (2011b) examined over 50 isolates obtained from finch trichomonosis cases and found no evidence for multiple strains, concluding that a clonal strain of Type A was

389 responsible for the emergence of epidemic trichomonosis in GB. Lawson et al., (2011b) 390 further speculated that due to the clonal nature of the passerine epidemic strain, it most 391 likely recently arose from a bottleneck, such as a single spill-over event (i.e., host392 switching) from columbids to sympatric finches. In the present study, ITS region 393 sequence analysis revealed that all Type A isolates from the Canadian Maritime 
394 provinces were identical to the UK finch epidemic strain. Furthermore, our examination 395 of the Fe-hyd gene also revealed that several finch and rock pigeon isolates were 396 identical to the UK finch epidemic strain (Lawson et al. 2011b). However, it is equally 397 important that Fe-hyd sequence analysis also revealed single nucleotide polymorphisms amongst some of the Canadian Type A isolates. Based on Fe-hyd nucleotide sequence analysis, four Canadian Type A isolates, including American goldfinch, purple finch and rock pigeon isolates, and one Canadian Type B isolate, only from a rock pigeon, were 401 found to be different from both the clonal UK epidemic strain and the Canadian Maritime 402 provinces' isolates similar to the clonal UK epidemic strain mentioned above (see 403 Figures 2 and 3). This suggests divergence not only from the British finch and Seychelles columbid strains they were compared to, but also from each other, indicating that a number of strains of $T$. gallinae are present in the wild avifauna of the Canadian Maritime provinces. Analysis of the Fe-hyd gene sequences from the Canadian Maritime provinces bird isolates showed that there is fine-scale variation amongst isolates akin to that observed in UK columbid populations. This observation suggests that the emergence of finch trichomonosis in this region may have been caused by multiple spill-over events, either from sympatric columbids, another bird species as yet

411 unknown to be infected with the parasite or from virulent $T$. gallinae developing 412 independently within the Canadian Maritime provinces' finch populations. In support of 413 this view a recent paper has reported the presence of the UK finch epidemic subtype A1 414 in North American columbids (Girard et al. 2014) similar to the findings in this study. Indeed, when historic $T$. gallinae DNA samples were subtyped, the A1 subtype 416 had also been isolated from Mauritian columbids sampled in 2004 (unpublished data) 
417 suggesting distribution of this subtype may actually be longstanding and global. Other reports of finch trichomonosis in North America have since emerged in west and eastcentral United States of America (Gerhold 2009) and western Canada (Canadian Cooperative Wildlife Health Centre unpublished data) in 2009. During the winter and spring of 2009, the Southeastern Cooperative Wildlife Disease Study (SCWDS) conducted PMEs on passerines of multiple species, including American goldfinch, house finch (Carpodacus mexicanus), northern cardinal (Cardinalis cardinalis), pine siskin and purple finch, submitted from mortality incidents from the eastern United States and found that whilst the majority had salmonellosis, at least 12 birds were suffering from trichomonosis or had concurrent infection with both of these pathogens which result in upper alimentary tract lesions (Hernandez et al. 2013; Gerhold 2009).

As with GB, there is evidence of some finch trichomonosis incidents in North America prior to the emergence of finch trichomonosis in the Canadian Maritime Provinces in 2007. On the western coast of the USA, Anderson et al. (2002) screened birds for trichomonad parasites on admission to a northern California wildlife rehabilitation facility over a period of four years (2001-2005) and found evidence of a low prevalence of the infection in the house finch $(1.7 \%)$ with a high case fatality rate (95.5\%); these authors hypothesised that the infection may be endemic in this (and other) passerine species in the region. Moreover, an outbreak affecting house finches, house sparrows and American goldfinches, contemporaneous with American mourning dove mortality (Zenaida macroura), occurred in the Midwest (Kentucky, Ohio and Indiana) in the autumn of 2002. A combination of trichomonosis and West Nile virus (WNV) infection was diagnosed as the cause of mortality (estimated total of 200 birds) 
440 although the relative importance of these agents was not described (NWHC 2002). In 441 the summer of 2006, a mixed species mortality incident of circa 200 birds involving 442 house finches, American goldfinches and a gray catbird (Dumetella carolinensis) was 443 reported to the SCWDS. Eighteen birds were submitted for PME with trichomonosis 444 confirmed in ten cases and WNV infection detected in one bird (Gerhold 2009). Various potential routes exist through which the UK finch epidemic strain of $T$. 446 gallinae could have been introduced to the Canadian Maritime Provinces. Bird migration 447 is believed to be the primary route of spread of the disease within Europe. Large 448 numbers of the finch and columbid species in which trichomonosis has been most 449 frequently diagnosed in GB in recent years have been banded (1960-2012 inclusive) 450 (greenfinch $n=2,107,976$, chaffinch $n=1,287,396$, goldfinch (Carduelis carduelis) $n=$ 451466,108 , siskin (Carduelis spinus) $n=503,097$ and collared dove $n=37,780$, wood pigeon $452 n=45,823)$ : however, no banded birds of these species have been recovered in North 453 America over that period suggesting international exchange is negligible (Robinson and 454 Clark 2013). Indeed, there are remarkably few exchanges of any British wild bird 455 species recorded with North America, with the most frequent being for seabirds and 456 waders, including the kittiwake (Rissa tridactyla) $n=73$, Manx shearwater (Puffinus 457 puffinus) $n=25$, knot (Calidris canutus) $n=19$, turnstone (Arenaria interpres) $n=14$, and 458 fulmar (Fulmarus glacialis) $n=13$; all other species with $<10$ individual birds recorded as 459 North American band recoveries are seabirds, shorebirds or waterfowl species in which 460 T. gallinae infection has not been recorded (Robinson and Clark, 2013). Collectively, 461 therefore bird migration from Europe is an unlikely route of introduction. Since $T$. 462 gallinae is not capable of long-term environmental persistence, movement with fomites 
463 is also an implausible method of parasite translocation. Anthropogenic movement of 464 captive birds, whether deliberate (e.g. cage and aviary birds, game birds, zoological 465 collections) or accidental (e.g. wild bird stowaways or stray racing pigeons) could have 466 occurred; however, there is no available evidence to support or refute this hypothesis 467 further. Collectively, therefore, whilst the emergence of finch trichomonosis in the 468 Canadian Maritime Provinces occurred shortly after the emergence of the disease in GB 469 in time, there is no clear candidate for a plausible route of introduction of the finch 470 epidemic strain of $T$. gallinae from the UK. Instead, there is evidence that favours the hypothesis that finch trichomonosis 472 emerged locally in the Canadian Maritime Provinces, through spillover from sympatric

473 birds; this route is most consistent with the SNPs in Fe-hyd subtypes found amongst the 474 finch and columbid isolates from PEI. The occurrence of endemic finch trichomonosis in 475 western USA (Anderson et al. 2009), and other isolated finch mortality incidents due to 476 the disease, indicates that parasite strains with the potential to cause disease in 477 passerines have been present in North America for some time. Future studies should examine $T$. gallinae isolates using multiple gene regions, 479 or full genome sequencing, in order to provide more detailed information about their 480 genetics which could lead to a better understanding of the epidemiology of avian 481 trichomonosis and the mechanisms of disease emergence.

482 Acknowledgements The authors wish to thank the Canadian Cooperative Wildlife 483 Health Centre, Atlantic Region and the AVC Lobster Science Centre for technical 484 support, particularly Fiep DeBie and Adam Acorn, and use of equipment during the 
485 completion of this study. Dwaine Oakley, Holland College Wildlife Technology Program, 486 provided technical expertise and training for trapping, mist netting and handling birds.

487 Also thanks to Rob Robinson from the British Trust for Ornithology, UK, for his 488 assistance with the bird migration data.

489 Financial Support This research was funded through a grant from the Sir James Dunn 490 Animal Welfare Centre, Atlantic Veterinary College. Work in the UK was supported in 491 part by a grant from the John and Pamela Salter Foundation 
492

493

494

495

496

497

498

499

500

501

502

503

504

505

506

507

508

509

510

512

511 Felleisen, R. (1997). Comparative sequence analysis of 5.8S rDNA genes and internal

\section{References}

Anderson, N., Grahn, R., Van Hoosear, K. and BonDurant, B. (2009). Studies of trichomonad protozoa in free ranging songbirds: Prevalence of Trichomonas gallinae in house finches (Carpodacus mexicanus) and corvids and a novel trichomonad in mockingbirds (Mimus polyglottos). Veterinary Parasitology 161, 178-186.

Amin, A., Bilic, I., Liebhart, D. and Hess, M. (2014) Trichomonads in birds - a review. Parasitology 141, 733-747.

Boal, C. and Mannan, R. (1999). Comparative breeding ecology of Cooper's hawks in urban and exurban areas of southeastern Arizona. Journal of Wildlife Management 63:77-84.

Bunbury, N., Jones, C., Greenwood, A. and Bell, D. (2007). Trichomonas gallinae in Mauritian columbids: implications for an endangered endemic. Journal of Wildlife Diseases 43, 399-407.

Chi, J.F., Lawson, B., Durrant, C., Beckmann, K., John, S., Alrefaei, A.F., Kirkbride, K., Bell, D.J., Cunningham, A.A. and Tyler, K.M. (2013). The finch epidemic strain of Trichomonas gallinae is predominant in British non-passerines. Parasitology 140, 12341245.

Duff, J., Pennycott, T., Willmington, J. and Robertson, S. (2007). Emergence of garden bird trichomonosis. Veterinary Record 161:828. transcribed spacer (ITS) regions of trichomonadid protozoa. Parasitology 115, 111-119. 
513 Felsenstein, J. (1985). Confidence limits on phylogenies: An approach using the 514 bootstrap. Evolution 39, 783-791.

515 Forzán, M., Vanderstichel, R., Melekhovets, Y. and McBurney, S. (2010).

516 Trichomoniasis in finches from the Canadian Maritime provinces - An emerging

517 disease. Canadian Veterinary Journal 51, 391-396.

518 Ganas, P., Jaskulska, B., Lawson, B., Zadravec, M., Hess, M. and Bilic, I. (2014).

519 Multi-locus sequence typing confirms the clonality of Trichomonas gallinae isolates

520 circulating in European finches. Parasitology 141, 652-661.

521 Gaspar da Silva, D., Barton, E., Bunbury, N., Lunness, P., Bell, D. and Tyler, K.

522 (2007). Molecular identity and heterogeneity of trichomonad parasites in a closed avian 523 population. Infection, Genetics and Evolution 7, 433-440.

524 Gerhold, R. (2009). Trichomonosis in songbirds. SCWDS Briefs from Southeastern 525 Cooperative Wildlife Disease Study College of Veterinary Medicine 25, 6-7.

526 Gerhold, R.W., Maestas, L.P. and Harnage, P.M. (2013) Persistence of two

527 Trichomonas gallinae isolates in chlorinated and distilled water with or without organic 528 material. Avian Diseases 57,681-683.

529 Gerhold, R., Yablsey, M., Smith, A., Ostergaard, E., Mannan, W. and Fischer, JR. 530 (2008). Molecular characterization of the Trichomonas gallinae morphologic complex in 531 the United States. Journal of Parasitology 94, 1335-1341. 
532 Girard, Y.A., Rogers, K.H., Woods, L.W., Chouicha, N., Miller, W.A. and Johnson,

533 C.K. (2014). Dual-pathogen etiology of avian trichomonosis in a declining band-tailed

534 pigeon population. Infection, Genetics and Evolution 24, 146-156.

535 Grabensteiner, E., Bilic, I., Kolbe, T. and Hess, M. (2010). Molecular analysis of

536 clonal trichomonad isolates indicate the existence of heterogenic species present in

537 different birds and within the same host. Veterinary Parasitology 172, 53-64.

538 Hall, T. (1999). BioEdit: a user friendly biological sequence alignment editor and 539 analysis program for Windows 95/98/NT. Nucleic Acids Symposium 41, 95-98.

540 Hernandez, S.M., Keel, K., Sanchez, S., Trees, E., Gerner-Smidt, P., Adams, J.K., 541 Cheng, Y., Ray, A., Martin, G., Presotto, A., Ruder, M.G., Brown, J., Blehert, D.S., 542 Cottrell, W., Maurer, J.J. (2013). Epidemiology of a Salmonella enterica subsp.

543 enterica serovar Typhimurium strain associated with a songbird outbreak. Applied

544 Environmental Microbiology, 78,7290-7298.

545 Jukes, T.H. and Cantor, C.R. (1969). Evolution of protein molecules. In Mammalian

546 Protein Metabolism, (ed. Munro, H.N.), pp. 21-132. Academic Press, New York, US.

547 Kelly-Clark, W.K., McBurney, S., Forzan, M.J., Desmarchelier, M. and Greenwood, 548 S.J. (2013). Detection and characterization of a Trichomonas isolate from a 549 rehabilitated bald eagle (Haliaeetus leucocephalus). Journal of Zoo and Wildlife 550 Medicine, 44:1121-1124. 
551 Kleina, P., Bettim-Bandinell, J., Bonatto, S., Benchimol, M. and Bogo, M. (2004).

552 Molecular phylogeny of Trichomonadidae family inferred from ITS-1, 5.8S rDNA and 553 ITS-2 sequences. International Journal for Parasitology 34, 963-970.

554 Krone, O., Altenkamp, R. and Kenntner, N. (2005). Prevalence of Trichomonas

555 gallinae in Northern goshawks from the Berlin area of Northeastern Germany. Journal of 556 Wildlife Diseases 41, 304-309.

Lawson, B., Cunningham, A., Chantrey, J., Hughes, L., Kirkwood, J., Pennycott, T. and Simpson, V. (2006). Epidemic finch mortality. Veterinary Record 159, 367.

Lawson, B., Robinson, R., Neimanis, A., Handeland, K., Isomursu, M., Agren, E.O., Hamnes, I.S., Tyler, K.M., Chantrey, J., Hughes, L.A., Pennycott, T.W., Simpson, V.R., John, S.K., Peck, K.M., Toms, M.P., Bennett, M., Kirkwood, J.K. and Cunningham, A.A. (2011a). Evidence of spread of the emerging infectious disease, finch trichomonosis, by migrating birds. EcoHealth 8:143-53.

Lawson, B., Cunningham, A., Chantrey, J., Hughes, L.A., John, S.K., Bunbury, N., 565 Bell, D.J. and Tyler, K.M. (2011b). A clonal strain of Trichomonas gallinae is the aetiologic agent of an emerging avian epidemic disease. Infection, Genetics and

567 Evolution 11, 1638-1645.

Lawson, B., Robinson, R. A., Colvile, K. M., Peck, K. M., Chantrey, J., Pennycott, 569 T.W., Simpson, V. R., Toms, M. P. and Cunningham, A. A. (2012). The emergence 570 and spread of finch trichomonosis in the British Isles. Philosophical Transactions of the 571 Royal Society B 367, 2852-2863. 
572 Neimanis, A., Handeland, K., Isomursu, M., Agren, E., Mattsson, R., Hamnes, I.S.,

573 Bergsjø, B. and Hirvelä-Koski, V. (2010). First report of epizootic trichomoniasis in

574 wild finches (Family Fringillidae) in Southern Fennoscandia. Avian Diseases 54, 136-

575141.

576 Nei, M. and Kumar, S. (2000). Molecular Evolution and Phylogenetics. Oxford

577 University Press, New York.

578 National Wildlife Health Center (2002) Quarterly Wildlife Mortality Report October

5792002 - December 2002. United States Geological Survey. National Wildlife Heath

580 Center, U.S.A. Available:

581 http://www.nwhc.usgs.gov/publications/quarterly_reports/2002_qtr_4.jsp [Accessed

582 June 2009].

583 Pennycott, T., Lawson, B., Cunningham, A., Simpson, V. and Chantrey, J. (2005).

584 Necrotic ingluvitis in wild finches. Veterinary Record 157, 360.

585 Peters, M., Kilwinski, J., Reckling, D., Henning, K. (2009) Geha"ufte Todesfa“lle von 586 wild lebenden Grünfinken an Futterstellen infolge Trichomonas-gallinae-Infektionen-

587 ein aktuelles problem in Norddeutschland. Kleintierpraxis 54, 433-438.

588 Robinson, R.A. and Clark, J.A. (2013) The Online Ringing Report: Bird ringing in

589 Britain \& Ireland in 2012 BTO, Thetford (http://www.bto.org/ringing-report (accessed on $590 \quad 5 / 2 / 14)$

591 Robinson, R., Lawson, B., Toms, M., Peck, K.M., Kirkwood, J.K., Chantrey, J.,

592 Clatworthy, I.R., Evans, A.D., Hughes, L.A., Hutchinson, O.C., John, S.K., 
593 Pennycott, T.W., Perkins, M.W., Rowley, P.S., Simpson, V.R., Tyler, K.M. and 594 Cunningham, A.A. (2010). Emerging infectious disease leads to rapid population 595 declines of common British birds. PLoS ONE 8:e12215.

596 Sansano-Maestre, J., Garijo-Toledo, M. and Gómez-Muñoz, M. (2009). Prevalence 597 and genotyping of Trichomonas gallinae in pigeons and birds of prey. Avian Pathology $598 \quad 38,201-207$.

599 Simpson, V. and Molenaar, F. (2006). Increase in trichomonosis in finches. Veterinary 600 Record 159:606.

601 Stabler, R. 1954. Trichomonas gallinae: a review. Experimental Parasitology 3:368602402.

603 Tamura, K., Stecher, G., Peterson, D., Filipski, A. and Kumar, S. (2013). MEGA6:

604 Molecular Evolutionary Genetics Analysis Version 6.0. Molecular Biology and Evolution 605 30: 2725-2729.

606 
607 Figure 1. Geographical distribution of the sites in the Canadian Maritime provinces

608 where Trichomonas gallinae isolates were collected. Superscripts correspond to the

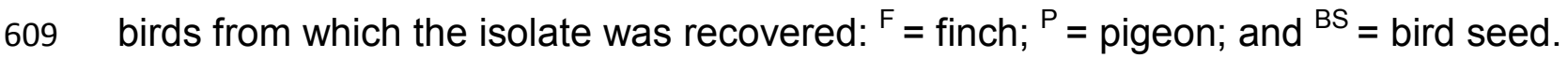

610 Refer to Table 1 for additional details for each isolate.

612 Figure 2. Neighbour-joining 60\% bootstrap-consensus tree based on Trichomonas

613 gallinae ITS region sequences. Values at nodes represent the bootstrap percentages

614 from 1,000 replicates for neighbour-joining, maximum parsimony and maximum

615 likelihood respectively. There were a total of 209 positions in the final dataset as all

616 positions containing gaps and missing data were eliminated. GenBank accession

617 numbers are given along with host names or isolate designations and country for each

618 trichomonad. Isolates in bold are from birds sampled in the present study. For additional

619 isolate details see Table 1. * indicates UK Finch epidemic strain.

620

621 Figure 3. Neighbour-joining 60\% bootstrap-consensus tree based on Trichomonas

622 gallinae Fe-hydrogenase gene sequences. Values at nodes represent the bootstrap

623 percentages from 1,000 replicates for neighbour-joining, maximum parsimony and

624 maximum likelihood respectively. There were a total of 803 positions in the final dataset.

625 GenBank accession numbers are given beside host names or isolate designations and 626 country for each trichomonad. Isolates in bold are from birds sampled and designated

627 into the six Fe-hyd subtypes identified in the present study. For additional isolate details 628 see Table 1. * indicates UK Finch epidemic strain. 
Table 1. Case data and Trichomonas gallinae isolates used for the ITS region and Fehydrogenase (Fe-hyd) gene PCR analyses. The last two digits of the year of collection are indicated as the first two digits of the case number. Bird state (alive or dead) indicates whether the sample was collected in-field from live-sampling or at necropsy. ITS typing and Fe-hyd subtyping results from sequence data are recorded.

\begin{tabular}{|c|c|c|c|c|c|c|c|}
\hline $\begin{array}{l}\text { Isolate } \\
\text { ID }\end{array}$ & $\begin{array}{l}\text { Case } \\
\text { no. }\end{array}$ & Species & $\begin{array}{l}\text { Bird } \\
\text { state }\end{array}$ & $\begin{array}{l}\text { Trichomonosis } \\
\text { Status }\end{array}$ & Site location & ITS type & $\begin{array}{l}\text { Fe-hyd } \\
\text { subtype }\end{array}$ \\
\hline 1 & 09-01 & $\begin{array}{l}\text { American } \\
\text { goldfinch }\end{array}$ & Alive & $\begin{array}{l}\text { Apparently } \\
\text { Healthy }\end{array}$ & $\begin{array}{l}\text { Vernon River, } \\
\text { PEI }\end{array}$ & A & 1 \\
\hline 2 & $09-02$ & $\begin{array}{l}\text { American } \\
\text { goldfinch }\end{array}$ & Alive & $\begin{array}{l}\text { Apparently } \\
\text { Healthy }\end{array}$ & $\begin{array}{l}\text { Vernon River, } \\
\text { PEI }\end{array}$ & A & 1 \\
\hline 3 & $09-07$ & $\begin{array}{l}\text { American } \\
\text { goldfinch }\end{array}$ & Alive & $\begin{array}{l}\text { Apparently } \\
\text { Healthy }\end{array}$ & $\begin{array}{l}\text { Vernon River, } \\
\text { PEI }\end{array}$ & A & 1 \\
\hline 4 & $09-14$ & $\begin{array}{l}\text { American } \\
\text { goldfinch }\end{array}$ & Alive & $\begin{array}{l}\text { Apparently } \\
\text { Healthy }\end{array}$ & $\begin{array}{l}\text { New Haven, } \\
\text { PEI }\end{array}$ & A & 1 \\
\hline 5 & $09-28$ & $\begin{array}{l}\text { American } \\
\text { goldfinch }\end{array}$ & Alive & $\begin{array}{l}\text { Apparently } \\
\text { Healthy }\end{array}$ & $\begin{array}{l}\text { New Haven, } \\
\text { PEI }\end{array}$ & A & 1 \\
\hline 6 & $11-116$ & $\begin{array}{l}\text { American } \\
\text { goldfinch }\end{array}$ & Alive $^{\dagger}$ & Trichomonosis & Orwell, PEI & A & 1 \\
\hline 7 & $11-122$ & $\begin{array}{l}\text { American } \\
\text { goldfinch }\end{array}$ & Alive & Trichomonosis & Orwell, PEI & A & 3 \\
\hline 8 & 09-04 & Purple finch & Alive $^{\dagger t}$ & Trichomonosis & $\begin{array}{l}\text { Vernon River, } \\
\text { PEI }\end{array}$ & $A$ & 2 \\
\hline 9 & $09-08$ & Purple finch & Alive & Trichomonosis & $\begin{array}{l}\text { Vernon River, } \\
\text { PEI }\end{array}$ & A & 2 \\
\hline 10 & $09-12$ & Purple finch & Alive & $\begin{array}{l}\text { Apparently } \\
\text { Healthy }\end{array}$ & $\begin{array}{l}\text { Vernon River, } \\
\text { PEI }\end{array}$ & A & 2 \\
\hline 11 & $09-13$ & Purple finch & Alive & $\begin{array}{l}\text { Apparently } \\
\text { Healthy }\end{array}$ & $\begin{array}{l}\text { Vernon River, } \\
\text { PEI }\end{array}$ & A & 1 \\
\hline
\end{tabular}


$12 \quad 09-15$ Purple finch Alive Trichomonosis Vernon River, A 1 PEI

$13 \quad$ 09-24 Purple finch Alive

Apparently

New Haven,

A

1 Healthy

PEI

14 11-29 Purple finch Dead Trichomonosis

Durham

A Bridge, NB

15 11-31 Purple finch Alive $^{\dagger \dagger}$

Apparently

Durham

A

1

Healthy

Bridge, NB

Purple finch

Alive

Apparently

Durham

A

1

Healthy

Bridge, NB

Purple finch

Alive

Apparently

Durham

A

Bridge, NB

Purple finch Alive $^{\dagger \dagger}$

Healthy

Durham

A

3

Healthy

Bridge, NB

11-100 Purple finch

Dead

Trichomonosis

Pointe-du-

A

1

Chêne, NB

Purple finch

Alive

Apparently

Healthy

Pointe-du-

A

Chêne, NB

Purple finch

Alive

Trichomonosis

Orwell, PEI

A

1

22

11-114 Purple finch

Alive $^{\dagger}$

Trichomonosis

Orwell, PEI

A

1

23

$11-11$

Purple finch

Alive Trichomonosis

Orwell, PEI

A

1

24

$11-117$

Purple finch

Alive

Trichomonosis

Orwell, PEI

A

1

25

11-119

Purple finch

Alive

Trichomonosis

Orwell, PEI

A

1

26

$11-120$

Purple finch

Alive

Trichomonosis

Orwell, PEI

A

1

27

$11-121$

Purple finch

Alive

Trichomonosis

Orwell, PEI

A

1

28

11-124 Purple finch

Alive

Trichomonosis

Orwell, PEI

A

1

29

11-146 Purple finch

Dead

Trichomonosis

Montague, PEI A 


\begin{tabular}{|c|c|c|c|c|c|c|c|}
\hline & & & & Healthy & PEI & & \\
\hline 31 & $10-09$ & Rock pigeon & Alive & $\begin{array}{l}\text { Apparently } \\
\text { Healthy }\end{array}$ & $\begin{array}{l}\text { Charlottetown, } \\
\text { PEI }\end{array}$ & A & 1 \\
\hline 32 & $10-12$ & Rock pigeon & Alive & $\begin{array}{l}\text { Apparently } \\
\text { Healthy }\end{array}$ & $\begin{array}{l}\text { Charlottetown, } \\
\text { PEI }\end{array}$ & A & 1 \\
\hline 33 & $10-14$ & Rock pigeon & Alive & $\begin{array}{l}\text { Apparently } \\
\text { Healthy }\end{array}$ & $\begin{array}{l}\text { Charlottetown, } \\
\text { PEI }\end{array}$ & B & 6 \\
\hline 34 & $10-16$ & Rock pigeon & Alive & $\begin{array}{l}\text { Apparently } \\
\text { Healthy }\end{array}$ & $\begin{array}{l}\text { Charlottetown, } \\
\text { PEI }\end{array}$ & A & 1 \\
\hline 35 & $11-06$ & Rock pigeon & Alive & $\begin{array}{l}\text { Apparently } \\
\text { Healthy }\end{array}$ & $\begin{array}{l}\text { New } \\
\text { Dominion, PEI }\end{array}$ & A & 1 \\
\hline 36 & $11-07$ & Rock pigeon & Alive & $\begin{array}{l}\text { Apparently } \\
\text { Healthy }\end{array}$ & $\begin{array}{l}\text { New } \\
\text { Dominion, PEI }\end{array}$ & B & 6 \\
\hline 37 & $11-08$ & Rock pigeon & Alive & $\begin{array}{l}\text { Apparently } \\
\text { Healthy }\end{array}$ & $\begin{array}{l}\text { New } \\
\text { Dominion, PEI }\end{array}$ & A & 1 \\
\hline 38 & $11-09$ & Rock pigeon & Alive & $\begin{array}{l}\text { Apparently } \\
\text { Healthy }\end{array}$ & $\begin{array}{l}\text { New } \\
\text { Dominion, PEI }\end{array}$ & A & 1 \\
\hline 39 & $11-12$ & Rock pigeon & Dead & Trichomonosis & $\begin{array}{l}\text { Charlottetown, } \\
\text { PEI }\end{array}$ & A & 4 \\
\hline 40 & $11-13$ & Rock pigeon & Dead & $\begin{array}{l}\text { Apparently } \\
\text { Healthy }\end{array}$ & $\begin{array}{l}\text { Murray River, } \\
\text { PEI }\end{array}$ & A & 5 \\
\hline 41 & $11-151$ & Rock pigeon & Dead & $\begin{array}{l}\text { Apparently } \\
\text { Healthy }\end{array}$ & $\begin{array}{l}\text { Charlottetown, } \\
\text { PEI }\end{array}$ & B & 6 \\
\hline 42 & 09-BF & Bird seed & $N / A$ & $N / A$ & $\begin{array}{l}\text { New Haven, } \\
\text { PEI }\end{array}$ & $A$ & $\mathrm{NE}^{\dagger+}$ \\
\hline
\end{tabular}

\footnotetext{
${ }^{\dagger}$ died immediately after swabbing (approx. 45 minutes), confirmed trichomonosis as cause of death via post-mortem examination. ${ }^{\dagger \dagger}$ died after swabbing (days to weeks), confirmed trichomonosis as cause of death via post-mortem examination

${ }^{\mathrm{t}} \mathrm{NE}$ - Not evaluated as the PCR was unsuccessful.
} 


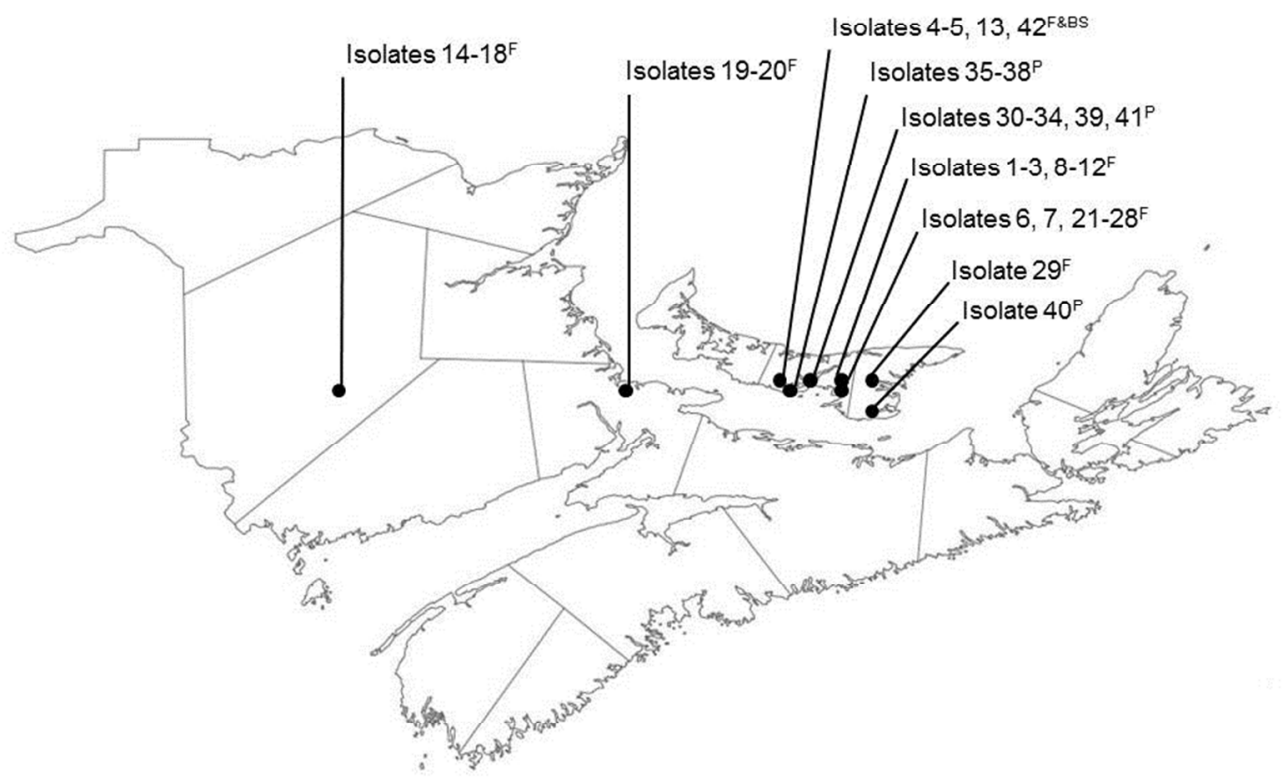

$160 \times 120 \mathrm{~mm}(152 \times 152 \mathrm{DPI})$ 


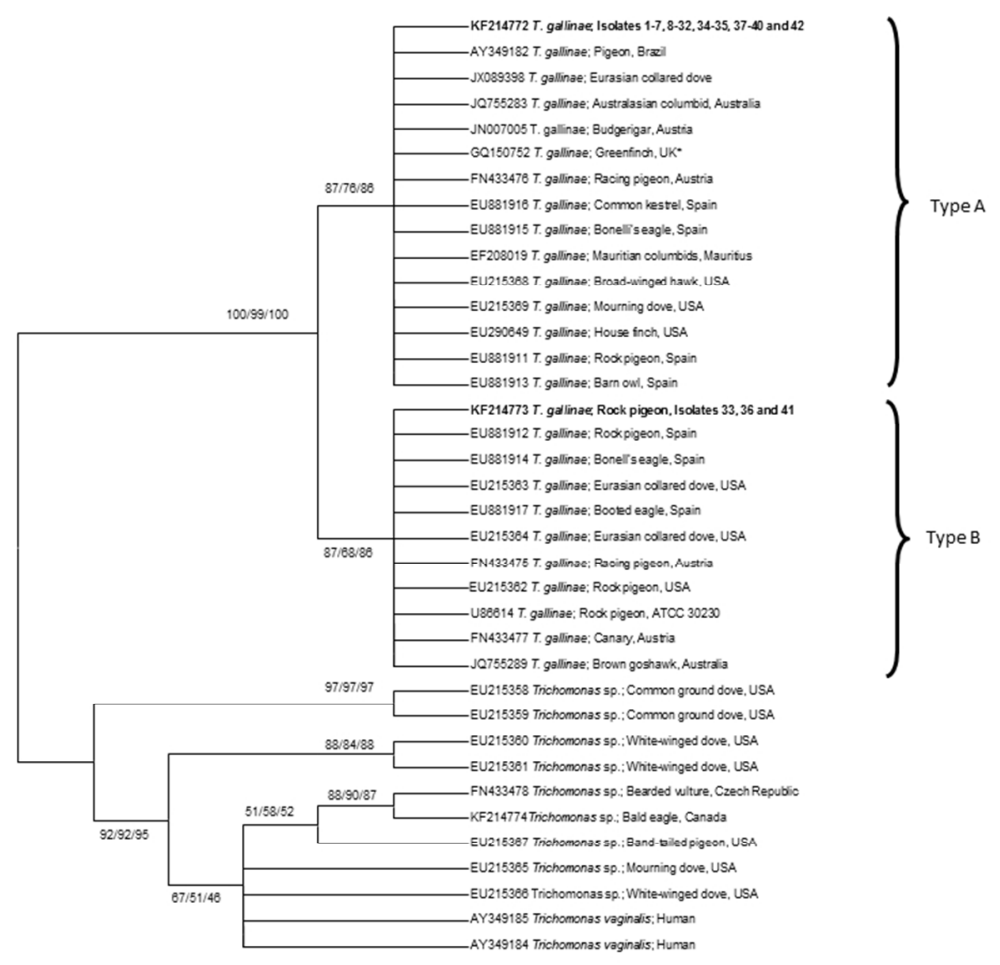

$160 \times 120 \mathrm{~mm}(152 \times 152 \mathrm{DPI})$ 


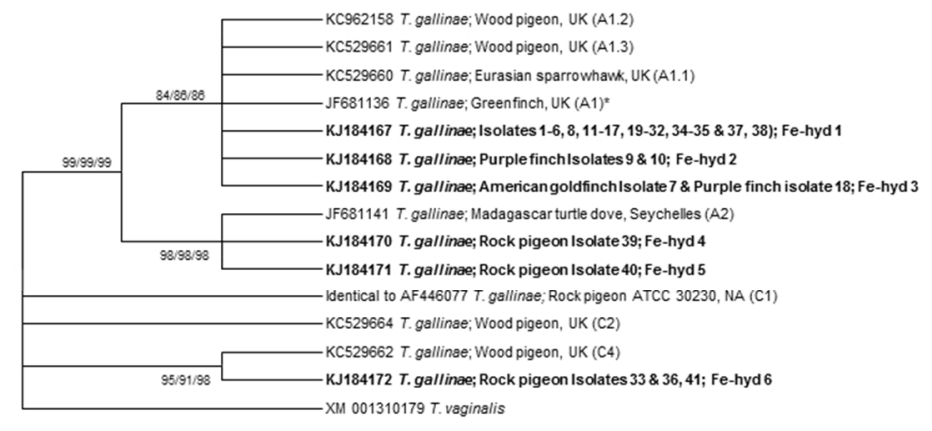

$160 \times 120 \mathrm{~mm}(152 \times 152 \mathrm{DPI})$ 